Article

\title{
Sulfonated Cellulose-Based Magnetic Composite as Useful Media for Water Remediation from Amine Pollutants
}

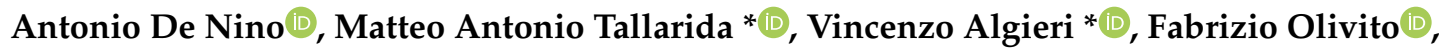

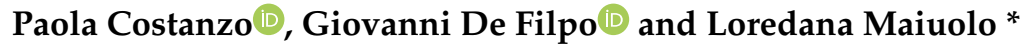 \\ Department of Chemistry and Chemical Technologies, University of Calabria, Via P. Bucci, \\ 87036 Rende (CS), Italy; denino@unical.it (A.D.N.); fabrizio.olivito@unical.it (F.O.); \\ paola.costanzo@unical.it (P.C.); defilpo@unical.it (G.D.F.) \\ * Correspondence: matteoa.tallarida@unical.it (M.A.T.); vincenzo.algieri@unical.it (V.A.); \\ maiuolo@unical.it (L.M.)
}

Received: 1 October 2020; Accepted: 15 November 2020; Published: 18 November 2020

Featured Application: A novel composite based on magnetite-decorated sulfate cellulose nanoparticles (MDSCNs) was prepared and used in water remediation from amine pollutants.

\begin{abstract}
Commercially available microcrystalline cellulose (MCC) was functionalized using chlorosulfonic acid, while iron oxide nanoparticles (IONPs) were adsorbed on the surface of the cellulose derivative by the Massart's co-precipitation method. The obtained magnetite-decorated sulfate cellulose nanoparticles (MDSCNs) were characterized via Fourier transform infrared (FTIR) spectroscopy, scanning-electron microscopy (SEM), and elemental analysis, while the acidity of the functionalized cellulose was determined using an acid-base titration with phenolphthalein as an indicator. Furthermore, in order to determine the adsorptive power of the obtained composite, a series of analyses were performed on aqueous amine pollutants using flame ionization detection gas chromatography (GC-FID). The results of this study clearly show how a bio-compatible green polymer as cellulose can be easy functionalized in order to improve its chemical and physical properties, obtaining a magnetic composite useful in water purification. Adsorption percentages up to $90 \%$ and a very small amount of composite used $(100 \mathrm{mg})$ proved how our material can be a powerful tool in environmental remediation.
\end{abstract}

Keywords: amines removal; water remediation; iron oxide nanoparticles; sulfonated cellulose; water pollutants

\section{Introduction}

Since their appearance in world scientific panorama, nanomaterials (NMs) inspired uncountable applications in modern science. NMs have been widely applied in theranostics [1], in vivo imaging [2], and in the development of nanoscaled drug delivery systems (DDSs) [3-7]. Environmental sciences [8] and the food industry [9] proposed many nanotechnology-based solutions too, whose strategies can be traced back to the self- or induced-molecular assembly, quite often involving amphiphilic species [10].

Of all NMs, nanoparticles (NPs) gained a huge importance in many fields [11]. More thoroughly, iron oxide nanoparticles (IONPs or IONs) are an important class of NPs made up by hematite, which is an abundant bio-friendly oxidized-state of iron. Iron oxide crystals can arrange in four main phases called magnetite $\left(\mathrm{Fe}_{3} \mathrm{O}_{4}\right)$, goethite $(\mathrm{FeOH})$, maghemite $\left(\gamma-\mathrm{Fe}_{2} \mathrm{O}_{3}\right)$, and hematite $\left(\alpha-\mathrm{Fe}_{2} \mathrm{O}_{3}\right)[12]$. IONPs possess a diameter that spans between 20 and $150 \mathrm{~nm}$ and a great magnetic susceptibility. 
Furthermore, under $20 \mathrm{~nm}$, IONs exhibit a superparamagnetic behavior, revealing their magnetic properties only if an external field is applied [13]. $\mathrm{Fe}_{3} \mathrm{O}_{4}$ is often preferred for its $\mathrm{Fe}^{2+}-\mathrm{Fe}^{3+}$ ions ratio and for the strongest magnetic properties of all transition metals oxides possessed [14]. For the reasons mentioned above, superparamagnetic iron oxide nanoparticles (SPIONs) are a well-established therapeutic instrument that has been already approved by the Food and Drug Administration (FDA) in some formulations [7].

IONPs can be also considered useful medias in conferring magnetic properties to amagnetic materials $[15,16]$. The preparation of composite materials enormously extends the applicability of NPs, since bare SPIONs show the tendency to form hydrophobic aggregate, which could limit their potential $[17,18]$.

The parameters considered in choosing the materials strongly depend on the final application of the composite. Furthermore, they should be also cheap and chemically versatile, so as to make more affordable their functionalization. Keeping clear in mind the environmental aim of this paper, many natural polysaccharides reflect such properties. For instance, chitin, chitosan, and nonionic galactomannans showed a good capacity to adsorb dyes in water due to their ability to take part in electrostatic interactions, van der Waals forces, and hydrogen bonds [19]. Starch derivatives as cyclodextrins and cycloamyloses were, as well, extensively applied for the removal of various organic pollutants $[20,21]$.

Lignocellulosic biomasses have been intensively applied to water remediation, too [22-24]. They are principally available as hemicellulose, cellulose, and lignin [25]. Particularly, cellulose presents a highly ordered reticulated structure, which can be considered at the basis of biomass recalcitrance [26] and of its high thermal resistance to depolymerization [27]. As a consequence of the great number of potential hydrogen bonds, cellulose and its derivatives can be employed to adsorb organic [28] and inorganic species $[29,30]$.

The main goal of this work was the applicative evaluation of a new type of versatile and easy-recoverable magnetic composite to purify water from amine pollutants. Generally, the organic chemistry allows researchers to plan and make numerous chemical handling and processing methods for organic substrates of various kinds, also thanks to the use of catalysis, solvent-free microwave, or non-conventional solvents [31-35]. It must be pointed out, in this respect, that novel binary mixtures of liquid amphiphiles are being recently studied, which, softly resembling ionic liquid properties, possess enhanced emerging properties, such as peculiar solubilizing properties toward inorganic salts and interesting intermolecular local self-assembly as a consequence of the local inherently anisotropic self-assembly [36-39]. Therefore, for substrates such as cellulose, which is more complex due to the presence of numerous primary and secondary hydroxyl groups, and recalcitrant for its stability due to intra- and intermolecular hydrogen bonds, it is necessary to develop more focused strategies of material synthesis and its recovery.

Inspired by the application of magnetic sorbents for wastewater remediation reviewed by Mehta et al. [40], we focused on synthesis of sulfonated (or sulfonic) cellulose (SC) for its promising ability to adsorb organic and inorganic species [41-44].

Among all the environmental applications, particularly urgent is the remediation of water from amines. Amines pollution is a widespread problem due to their intensive production in several industry sectors as oil refining, pharmaceuticals, pesticides, and so on $[45,46]$. Some amines show also a low biodegradability rate [47] and can be precursors of hazardous compounds [48,49], which makes the development of innovative materials for their removal highly necessary. The preparation of new materials for this kind of application is still mostly devoted to the use of carbon nanotubes (CNTs) and carbon-nitride derivatives, as reported by several authors [50-52]. Phyllosilicates too were employed as adsorbent for aromatic amines [53]. On the other hand, our work extends the use of polysaccharidic materials as amine adsorbents: a cheap, rapid, and eco-friendly approach for environmental remediation that was already explored using $\beta$-cyclodextrins [20] and chitosan-based [54] materials. The reduced number of adsorption studies mediated by SC and the urgency determined by these pollutants led 
us to focus our attention on aromatic and aliphatic amines. For these reasons, we developed a micrometric composite material bearing an acidic function on the cellulose's surface that is capable of electrostatic interactions with hydrochloride amines, which guarantee good recoveries with a small amount of adsorbent. Nonetheless, the magnetic properties conferred a simple and rapid recovery from the sample.

\section{Materials and Methods}

All reagents were furnished by Sigma Aldrich and used without any further purification. The purity of amines was verified to be the commercial one by GC analysis (see chromatograms in Supplementary Materials).

\subsection{Magnetic Nanoparticles Preparation and Characterization}

The magnetic composite was prepared starting from the functionalization of microcrystalline cellulose (MCC). The reaction was performed using chlorosulfonic acid $\left(\mathrm{ClSO}_{3} \mathrm{H}\right)$ according to the procedures already reported in the literature [55-58] with some slight modifications. First, $10 \mathrm{~g}$ of MCC were dried overnight at $90{ }^{\circ} \mathrm{C}$ and suspended in $40 \mathrm{~mL}$ of dry hexane in inert atmosphere under vigorous mechanical stirring at room temperature. Then, $4 \mathrm{~g}$ of chlorosulfonic acid ( $36 \mathrm{mmol}$ ) were suspended in $10 \mathrm{~mL}$ of dry hexane and added dropwise at room temperature for $2 \mathrm{~h}$. The mixture was stirred for additional $4 \mathrm{~h}$ at room temperature after finishing the addition. The obtained pale-yellow solid was washed several times with hexane $(40 \mathrm{~mL})$, water $(100 \mathrm{~mL})$, acetone $(60 \mathrm{~mL})$, and dried at vacuum pump. The sulfonic derivative was characterized via Fourier transform infrared (FTIR), elemental analysis, SEM, and acid-base titration with $0.1 \mathrm{~N} \mathrm{NaOH}$ and phenolphthalein as an indicator in order to determine its acid content.

The final magnetic nanoparticles were prepared using a Massart's co-precipitation procedure adapted for the preparation of biopolymeric composites reported by Lassalle and coworkers [59]. First, $10 \mathrm{~g}$ of SC were placed in a three-necked round-bottom flask in dry conditions with $6.508 \mathrm{~g}$ of $\mathrm{FeCl}_{3} \cdot 6 \mathrm{H}_{2} \mathrm{O}(24 \mathrm{mmol})$ and $3.578 \mathrm{~g}$ of $\mathrm{FeSO}_{4} \cdot 7 \mathrm{H}_{2} \mathrm{O}(13 \mathrm{mmol})$. Therefore, $250 \mathrm{~mL}$ of distilled water were added, and the mixture heated at $60^{\circ} \mathrm{C}$ for $20 \mathrm{~min}$. Hence, the solution was heated at $80{ }^{\circ} \mathrm{C}$, and $50 \mathrm{~mL}$ of $17.5 \% \mathrm{w} / \mathrm{w}$ of $\mathrm{NaOH}$ solution were added dropwise $(2 \mathrm{~mL} / \mathrm{min}$ ca. rate), maintaining a strong stirring to prevent the aggregation of the solid. After the end of the dripping, the suspension was maintained under energic stirring at $80^{\circ} \mathrm{C}$ for another $60 \mathrm{~min}$. During the process, the solution turned from an initial light brown color to a black one, signaling the end of the reaction. The black suspension obtained was cooled at room temperature and decanted with an Nd magnet externally to the flask. The supernatant was removed, and the solid was washed with distilled water until neutral $\mathrm{pH}$. Finally, the product was washed three times with ethanol and dried at vacuum pump, obtaining $12.2 \mathrm{gr}$ of magnetic brown powder ( $2.2 \mathrm{~g}$ of adsorbed magnetite). The product was characterized using FTIR and SEM.

Elemental analysis was performed with a varioMICRO CHNS V4.0.10 (Elementar Analysensysteme $\mathrm{GmbH}$, Langenselbold, DE, Germany) analyzer allowing obtaining the degree of substitution (DS) of the SC per glucose unit, using the following Equation (1) [60]:

$$
\mathrm{DS}_{\mathrm{S}}=\frac{\mathrm{S}_{\%} / 32}{\mathrm{C}_{\%} / 72}
$$

FTIR spectra were acquired by a Shimadzu IRAffinity-1S Spectrometer (Shimadzu Italia S.r.l., Milano, IT, Italy) in the spectral region of 375 and $4000 \mathrm{~cm}^{-1}$ with a resolution of $1 \mathrm{~cm}^{-1}$, setting 50 scans for a single analysis and using the $\mathrm{KBr}$ pellets technique. The $\mathrm{KBr}$ pellets were obtained by mixing the sample with dry $\mathrm{KBr}$ powder (ratio 1:100) and pressing with a hydraulic press, at the pressure of 10 tons for $5 \mathrm{~min}$. The resulting pellets were placed in the appropriate compartment of the instrument and exposed to the FTIR light beam for analysis. 
Surface characterization of the materials was carried out by a LEO 420 digital scanning electron microscope (SEM) (LEO Electron Microscopy, Ltd., Cambridge, UK); all samples were placed on a standard holder (stub) and stained with a gold alloy to avoid electric charges and to improve the quality of the images. Observations were made using a 15,000 V electron beam at a working distance of $9 \mathrm{~mm}$ and an incline of $20^{\circ}$.

\subsection{Sample Preparation}

The samples containing the selected amines were prepared separately. For the aliphatic amines, the solutions were prepared dissolving $200 \mu \mathrm{L}$ of piperidine, $N, N$-diisopropylethylamine, 1,5-dimethylhexylamine, $\mathrm{N}$-ethylhexylamine, octylamine, 4-methoxybenzylamine, and a stoichiometric amount of hydrochloridic acid $37 \%$ in $50 \mathrm{~mL}$ of distilled water $(\mathrm{pH} \cong 5-5.5)$. The samples relative to the aromatic amines were prepared dissolving $150 \mu \mathrm{L}$ of aniline, $\mathrm{N}$-methylaniline, 2,4-dimethylaniline, $\mathrm{N}, \mathrm{N}$-diethylaniline, and a stoichiometric amount of hydrochloridic acid $37 \%$ in $50 \mathrm{~mL}$ of distilled water.

\subsection{Adsorption Experiments and Amines Analysis}

Adsorption experiments were performed at room temperature in glass test tubes, adding $100 \mathrm{mg}$ of adsorbent to $10 \mathrm{~mL}$ of sample solution. In order to maintain a regular and homogeneous mixing, a MS1 Minishaker was used at $1400 \mathrm{~min}^{-1}$. Basing on the results reported by Shi and co-workers [41], an adsorption time of $120 \mathrm{~min}$ and room temperature were employed. Moreover, the amount of adsorbent material was calculated as a function of the sulfonate groups and that $\mathrm{pH}$ value corresponds to the salification one of amines. Therefore, the composite was collected laterally using an $\mathrm{Nd}$ magnet, and the supernatant was recovered and treated with a stoichiometric amount of sodium carbonate. The sample was extracted three times with ethyl acetate $(3 \times 10 \mathrm{~mL})$, and the organic phase was concentrated by a rotary evaporator, reprising the analytes with $10 \mathrm{~mL}$ of ethyl acetate. The determination of the concentration of the amines was performed analyzing every sample three times using a gas chromatograph Thermo Fischer Scientific Focus Series, USA with a flame ionization detector (FID) (see Supplementary Materials for the chromatograms). The calibration curves were constructed using the linear regression method analyzing 5 samples of each amine in AcOEt at different concentrations, covering a linear dynamic range from ca. 60 to $1200 \mathrm{ppm}$ (see Supplementary Materials for the graphics). The percentages of amines removal were calculated using Equation (2):

$$
\operatorname{RE}(\%)=\frac{\mathrm{C}_{0}-\mathrm{C}_{\mathrm{e}}}{\mathrm{C}_{0}} \times 100
$$

where RE is the amine removal efficiency $(\%)$, and $C_{0}$ and $C_{e}$ are the initial and equilibrium concentration in the solution, respectively.

Loading factors were calculated using Equation (3) [28]:

$$
\mathrm{Q}=\frac{\left(\mathrm{C}_{0}-\mathrm{C}_{\mathrm{t}}\right) \mathrm{V}}{\mathrm{m}}
$$

where $Q$ is the amount of pollutant adsorbed onto a unit dry mass of sulfonic cellulose in $\mathrm{mg} / \mathrm{g}$. $\mathrm{C}_{0}$ and $\mathrm{C}_{\mathrm{t}}$ are the initial and the remaining concentrations of pollutant in the solution $(\mathrm{mg} / \mathrm{L})$ at initial time and time $\mathrm{t}$ (minutes), respectively. $\mathrm{V}$ is the volume of the pollutant solution in $\mathrm{L}$, and $\mathrm{m}$ is the weight of the dry $\mathrm{SC} @ \mathrm{Fe}_{3} \mathrm{O}_{4}$ composite in grams.

\section{Results and Discussion}

\subsection{Magnetic Nanoparticles Synthesis}

Considering our purpose to realize an alternative route for the removal of aromatic and aliphatic amines from water using an eco-compatible and easily removable magnetic composite material, 
we started from the functionalization of microcrystalline cellulose (MCC), using chlorosulfonic acid $\left(\mathrm{ClSO}_{3} \mathrm{H}\right)$ to introduce sulfates on the superficial hydroxide groups (Scheme 1).

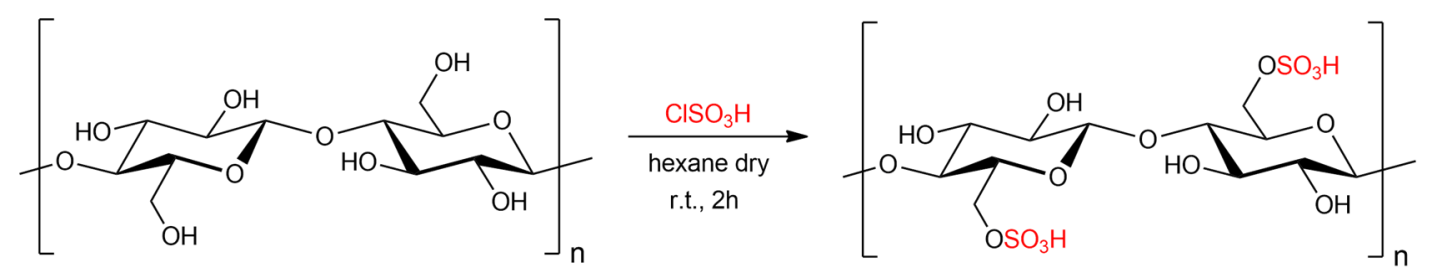

Scheme 1. Synthesis of functionalized microcrystalline cellulose.

The preparation of magnetite-decorated sulfate cellulose nanoparticles (MDSCNs), obtained by the coagulation of an aqueous suspension of sulfate cellulose containing a $\mathrm{Fe}^{2+} / \mathrm{Fe}^{3+}$ solution through the subsequent addition of aqueous $\mathrm{NaOH}$, is shown in Scheme 2.

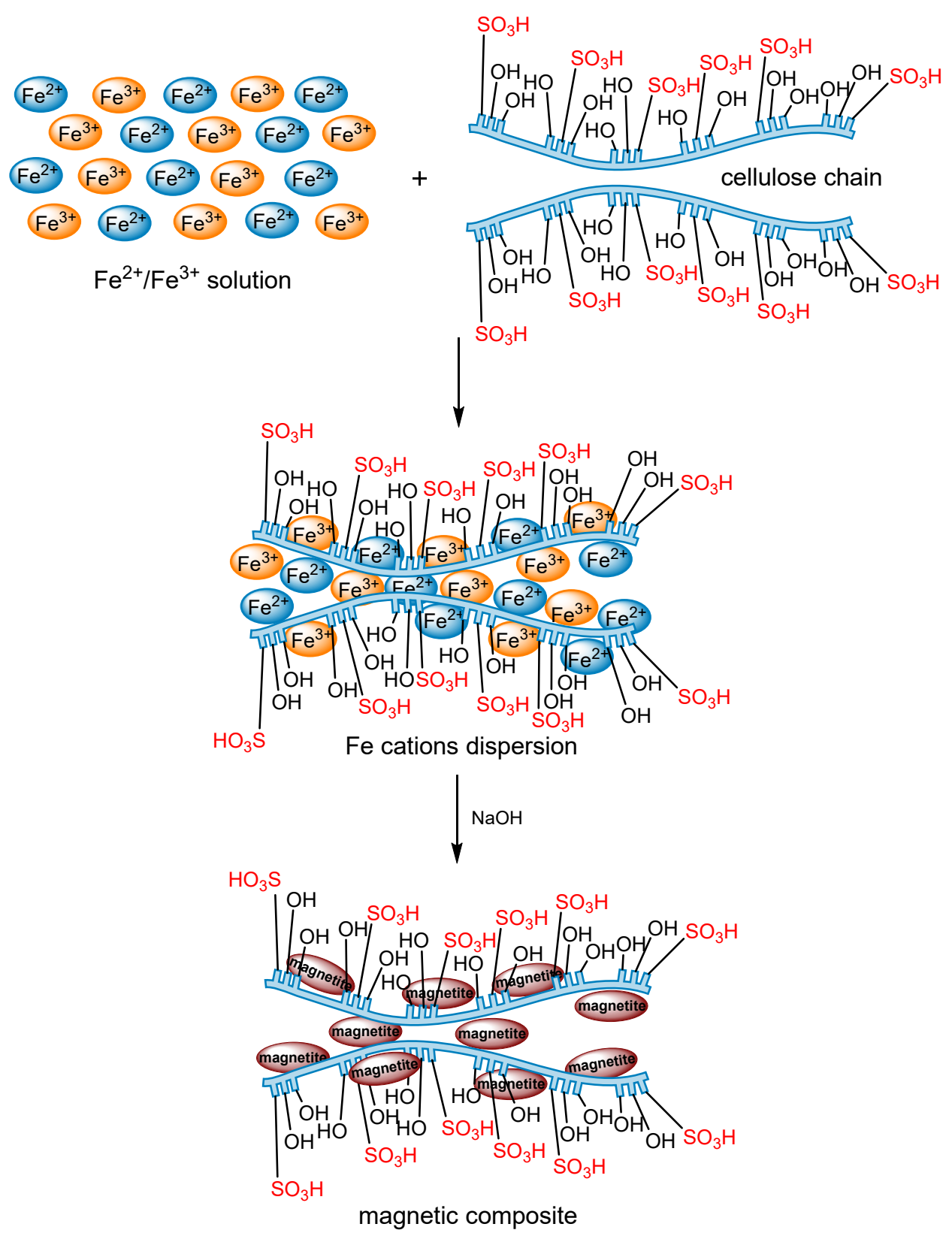

Scheme 2. Preparation of magnetite-decorated sulfate cellulose nanoparticles (MDSCNs). 
The used amount of iron salts was selected to form about $20 \%$ of magnetite with respect to the employed cellulose. This magnetite percentage turned out to be the minimum quantity to magnetize all cellulose.

\subsection{Characterization}

\subsubsection{FTIR}

The principal signal observed in the region over $3000 \mathrm{~cm}^{-1}$ was a single broad band ascribed to the O-H stretching vibration mode. In the case of the pure magnetite sample, the peak was due to the presence of traces of water in the sample [61]. For other samples, the broad band was unambiguously due to a series of vibrational stretching modes of the hydroxyl groups involved in diverse weak interactions [62].

Around $2900 \mathrm{~cm}^{-1}$, the FT-IR spectra of the polysaccharides and of the magnetic composite showed a peak relative to the C-H stretching of the polysaccharide structure [63]. In all of the spectra, around $1600 \mathrm{~cm}^{-1}$, the peak due to the bending vibrational modes of water was detected.

Except for the $\mathrm{Fe}_{3} \mathrm{O}_{4}$ spectrum, a series of peaks ascribed to the carbonic backbone of the polysaccharide were observed in the region between 1440 and $810 \mathrm{~cm}^{-1}$. The signal around $1430 \mathrm{~cm}^{-1}$ was attributed to the $-\mathrm{CH}_{2}$ bending mode [63]. On the other hand, the assignation of the peaks around 1370 and $1318 \mathrm{~cm}^{-1}$ were attributed to the vibration bending modes of the $\mathrm{C}-\mathrm{C}-\mathrm{H}, \mathrm{C}-\mathrm{O}-\mathrm{H}, \mathrm{O}-\mathrm{C}-\mathrm{H}$, and $-\mathrm{CH}_{2}$ groups, according the literature data $[64,65]$.

The peaks observed around 1164 and $1113 \mathrm{~cm}^{-1}$ were assigned to the skeletal deformation of the polysaccharidic chain [63]. The successive ones around 1059 and $1032 \mathrm{~cm}^{-1}$ were attributed to the C-C and C-O stretching vibration modes [66].

The peak at $896 \mathrm{~cm}^{-1}\left(816 \mathrm{~cm}^{-1}\right.$ for SC) was assigned to a vibration generated by the glucose ring deformation [65]: the low intensity of this signal can be related to a high degree of crystallinity of the biopolymer, meaning that no undesired hydrolysis reactions took place [67].

As highlighted in Figure 1, the region included between 1281 and $1206 \mathrm{~cm}^{-1}$ for the obtained sulfonic cellulose derivative presents the signals ascribed to the vibrational stretching of the sulfonic group [68]. The signals detected in the lowest region of the IR spectra (between 670 and $550 \mathrm{~cm}^{-1}$ ) were assigned to the deformation of the glucose unit of the polysaccharides. They were attributed to two glucose ring deformation vibration modes associated to the bending of the glycosidic bond [63].

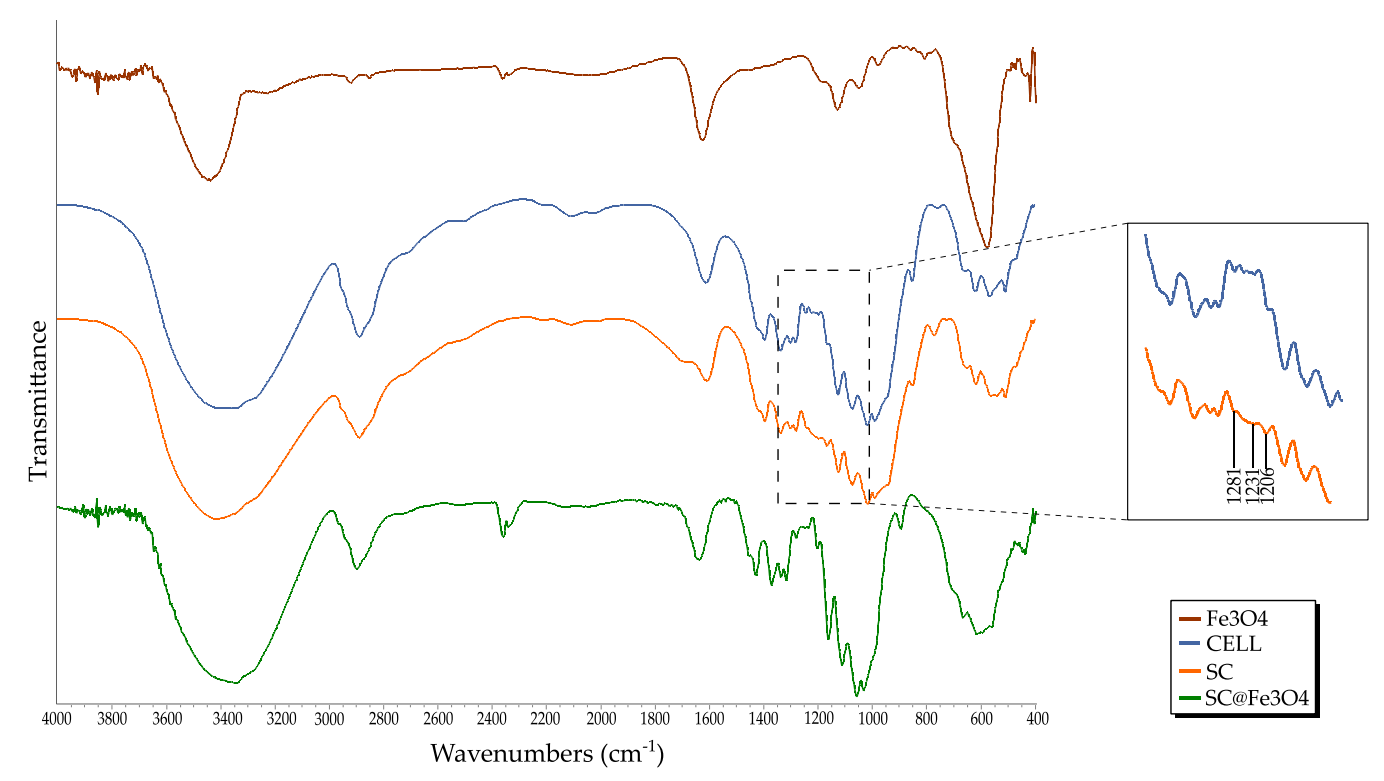

Figure 1. Fourier transform infrared (FTIR) spectra comparison between $\mathrm{Fe}_{3} \mathrm{O}_{4}$ IONs, cellulose (CELL), sulfonated cellulose (SC), and magnetic composite (SC@ $\left.\mathrm{Fe}_{3} \mathrm{O}_{4}\right)$. 
The signals at $578 \mathrm{~cm}^{-1}\left(\mathrm{Fe}_{3} \mathrm{O}_{4}\right.$ sample) and at $562 \mathrm{~cm}^{-1}\left(\mathrm{SC} @ \mathrm{Fe}_{3} \mathrm{O}_{4}\right)$ were assigned to the typical stretching vibration mode of the Fe-O bond [69] (see Supplementary Materials for the detailed spectra).

An IR spectrum was recorded after the absorption process of ammonium on the sulfonated magnetic nanocomposite, observing no detectable different of signals, which was probably due to the low amount of employed amine (see Supplementary Materials for IR spectra).

\subsubsection{Elemental Analysis}

The elemental analysis of the sulfonic derivative of MCC confirmed the functionalization of the biopolymer, allowing obtaining the degree of substitution per glucose unit (DS). The percentages of the elemental analysis calculated for $\mathrm{C}, \mathrm{H}, \mathrm{N}$, and $\mathrm{S}$ elements are summarized in Table 1.

Table 1. Percentages of the content of $\mathrm{C}, \mathrm{H}, \mathrm{N}$, and $\mathrm{S}$ for the sulfonated derivative.

\begin{tabular}{cccc}
\hline $\mathbf{C}(\mathbf{\%})$ & $\mathbf{H}(\mathbf{\%})$ & $\mathbf{N}(\mathbf{\%})$ & $\mathbf{S}(\mathbf{\%})$ \\
\hline 38.28 & 6.07 & 0.00 & 1.47 \\
\hline
\end{tabular}

On the basis of these results, the calculated DS (Equation (1)) was 0.09 per glucose unite, which is also referred as $0.46 \mathrm{mmol}$ per gram of material.

\subsubsection{Acid-Base Titration}

The acid-base titration was performed with $\mathrm{NaOH} 0.1 \mathrm{~N}$ and phenolphtalein as an indicator. The analysis furnished an acid content of $0.40 \mathrm{mmol} / \mathrm{g}$, which corresponds to about $87 \%$ of the global content of sulfur obtained from elemental analysis. This result showed how mostly of the sulfur in the material is in the form of sulfonic acid groups and mainly on the surface of the material.

\subsubsection{SEM}

The obtained magnetite-decorated sulfate cellulose nanoparticles (MDSCNs) were morphologically characterized by scanning-electron microscopy as reported in Figure 2.

A sample of cellulose/magnetite (CELL@ $\mathrm{Fe}_{3} \mathrm{O}_{4}$ ) composite was prepared following the same procedure reported in Section 2 and used as a comparison in order to evaluate the morphological variations with respect to the sulfonated cellulose/magnetite (SC@ $\left.\mathrm{Fe}_{3} \mathrm{O}_{4}\right)$ composite (Figure 3).

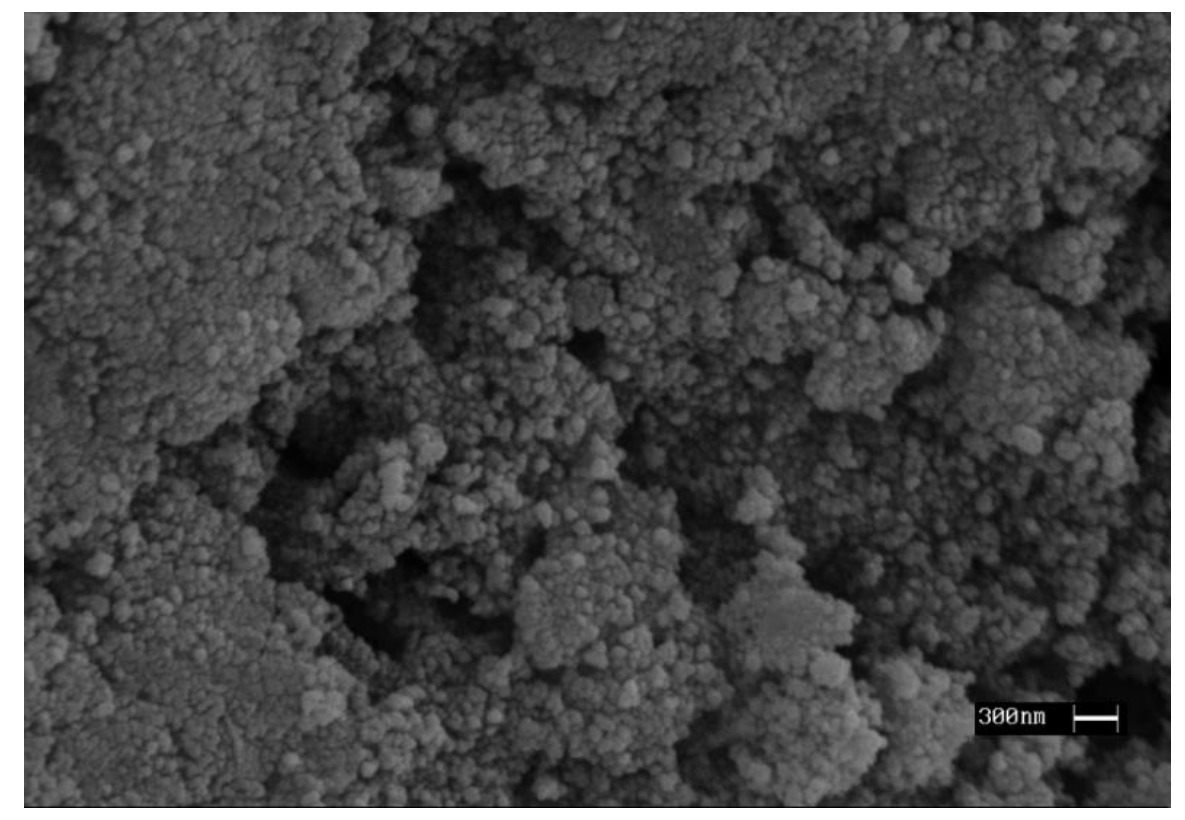

Figure 2. Morphological SEM characterization of MDSCNs (scale: $300 \mathrm{~nm}$ ). 

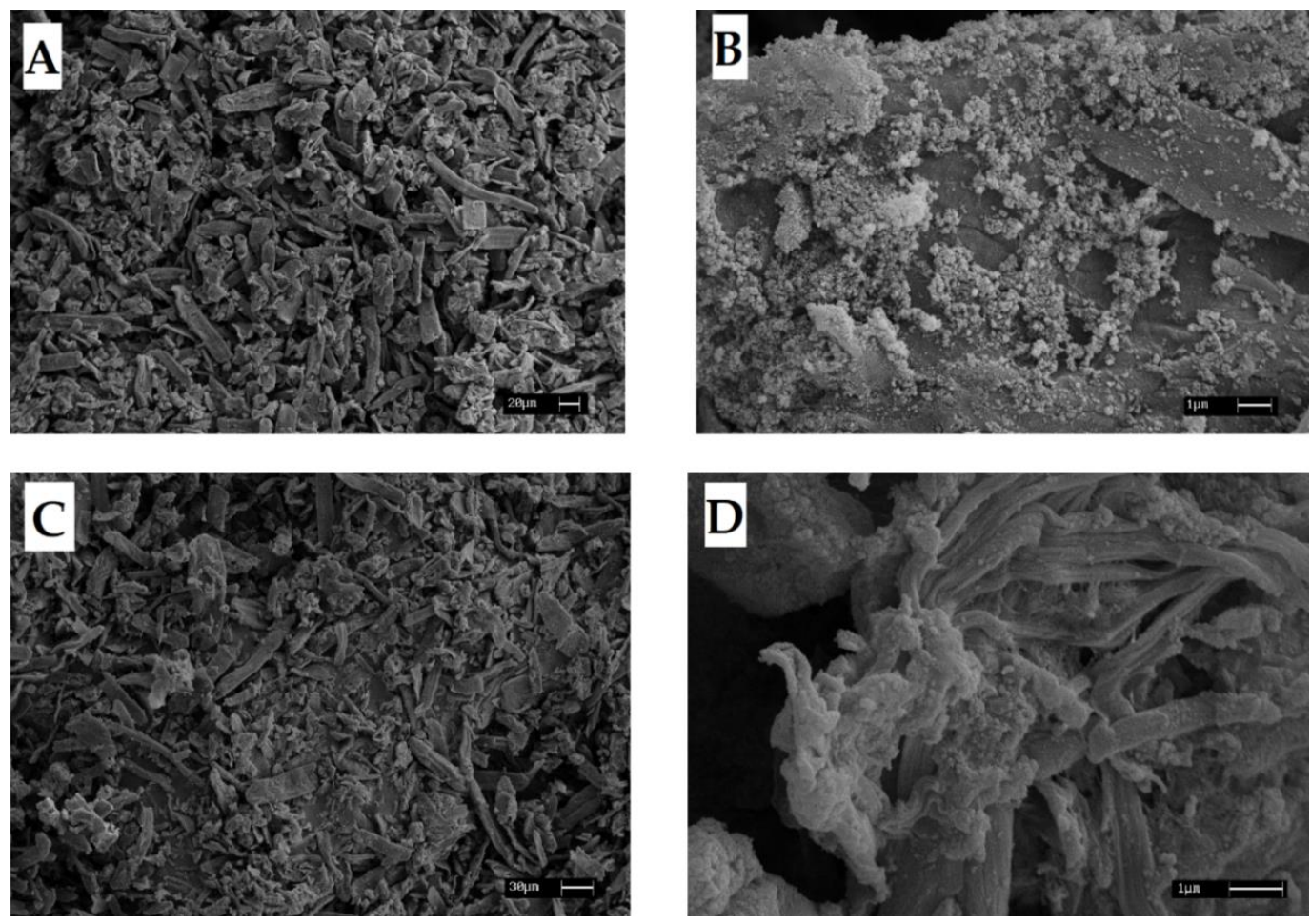

Figure 3. Morphological comparison between (A) CELL@ $@ \mathrm{Fe}_{3} \mathrm{O}_{4}$ (scale: $20 \mu \mathrm{m}$ ), (B) $\mathrm{CELL} @ \mathrm{Fe}_{3} \mathrm{O}_{4}$ (scale: $1 \mu \mathrm{m}$ ), (C) SC@Fe $\mathrm{O}_{4}$ (scale: $30 \mu \mathrm{m}$ ), and (D) $\mathrm{SC} @ \mathrm{Fe}_{3} \mathrm{O}_{4}$ (scale: $1 \mu \mathrm{m}$ ).

As can be observed, the $\mathrm{SC} @ \mathrm{Fe}_{3} \mathrm{O}_{4}$ composite presented some frayed regions (Figure 3C,D) not present in CELL@ $@ \mathrm{Fe}_{3} \mathrm{O}_{4}$ (Figure 3A,B). The increasing of the number of amorphous regions can be attributed to the chemical functionalization of the polysaccharide, which disrupted the hydrogen bonds and exposed the fibers inside the microcrystals. It also increased the contact surface available for the aggregation of the magnetite nanoparticles, which were found inside the structure of the sulfonated microcrystals (Figure 4).

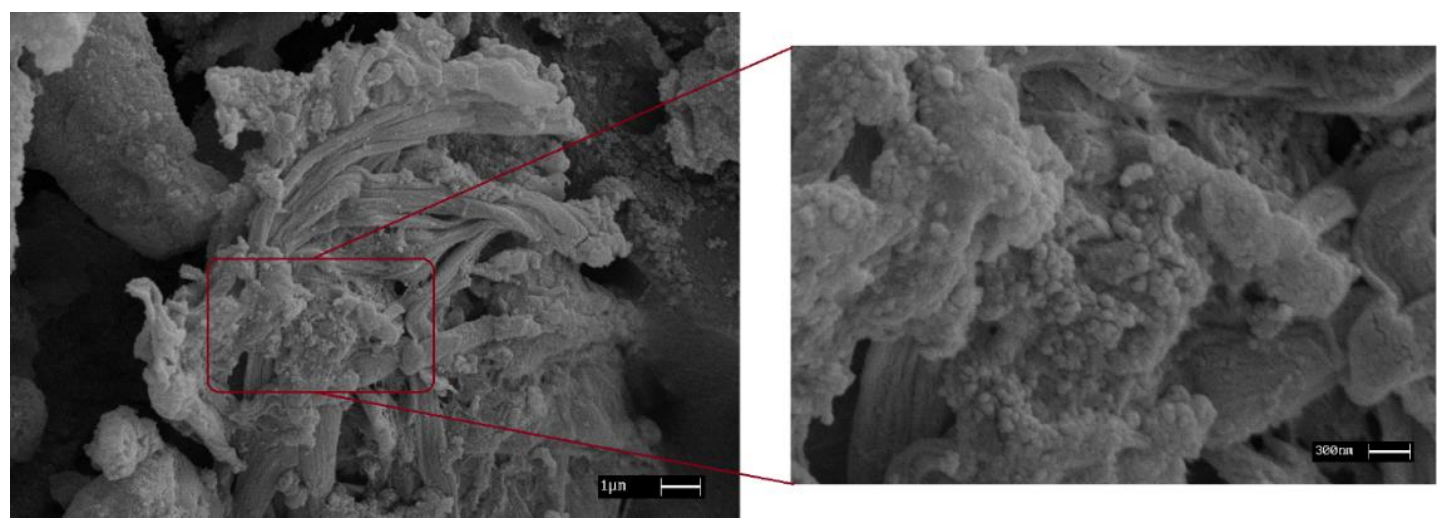

Figure 4. Magnification of a $\mathrm{SC} @ \mathrm{Fe}_{3} \mathrm{O}_{4}$ microcrystal (scale: $1 \mu \mathrm{m}$ and $300 \mathrm{~nm}$ ).

\subsection{Adsorption Studies}

The applicative evaluation of the obtained composite was performed testing its properties as an adsorbent for aliphatic and aromatic amines in water. The analytes were chosen in order to cover a broad range of chemical properties such as polarity and basicity. In this case, we wanted to take advantage of the electrostatic exchange interaction between the analytes in the form of hydrochloride 
amines and sulfonic groups on the surface of the composite. In Scheme 3, the ionic exchange mechanism is reported, in which the acid proton of a sulfonic group is substituted from an ammonium cation.

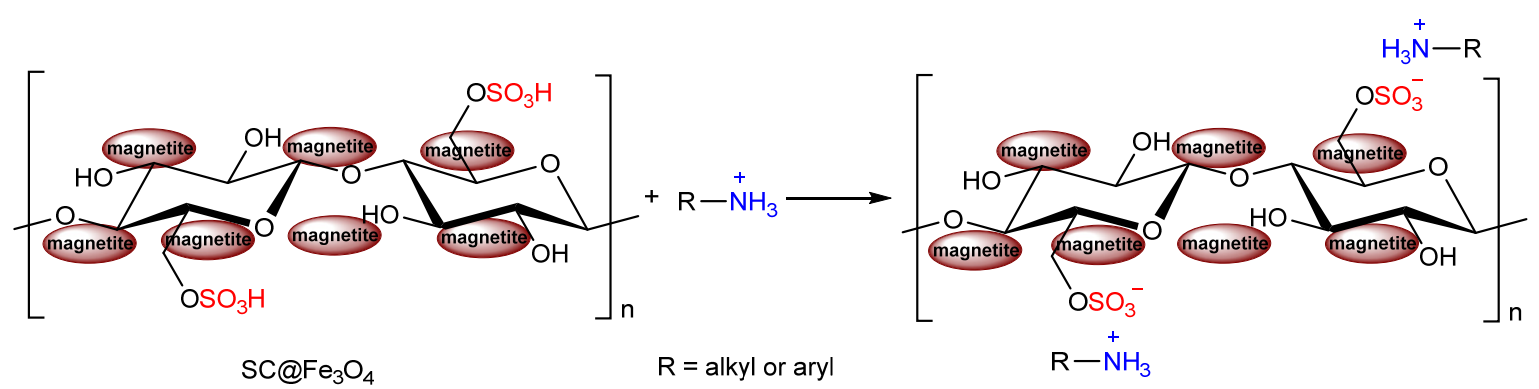

Scheme 3. Ionic exchange between ammonium ion and hydrogen of $\mathrm{SC}_{\mathrm{O}} \mathrm{F}_{3} \mathrm{O}_{4}$.

Furthermore, the magnetic susceptibility of the material allowed a rapid and simple recovery (Figure 5).

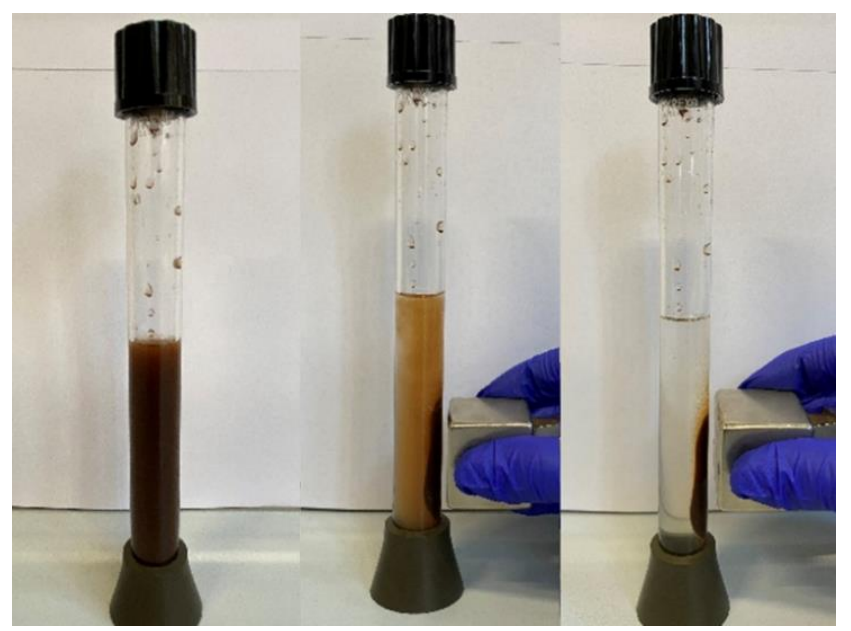

Figure 5. Separation of the magnetic composite after adsorption.

The adsorption trends are reported in Figure 6.

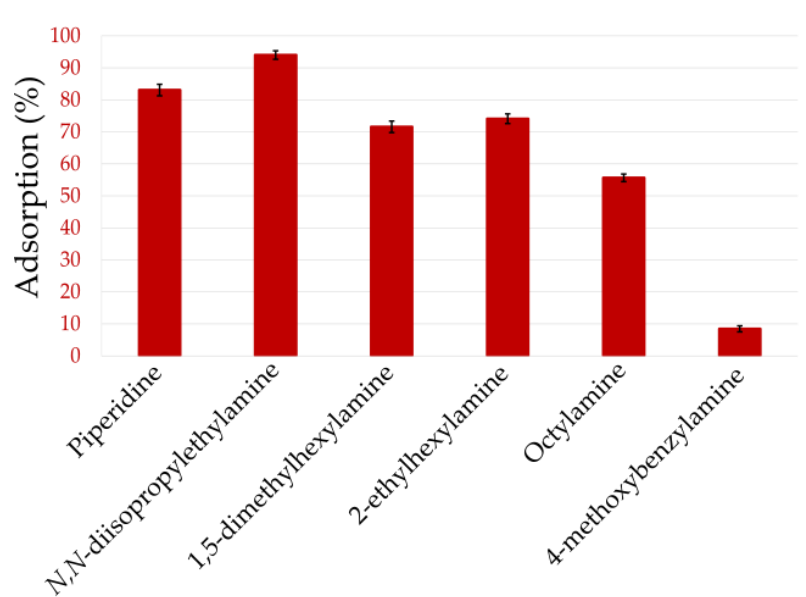

Aliphatic amines

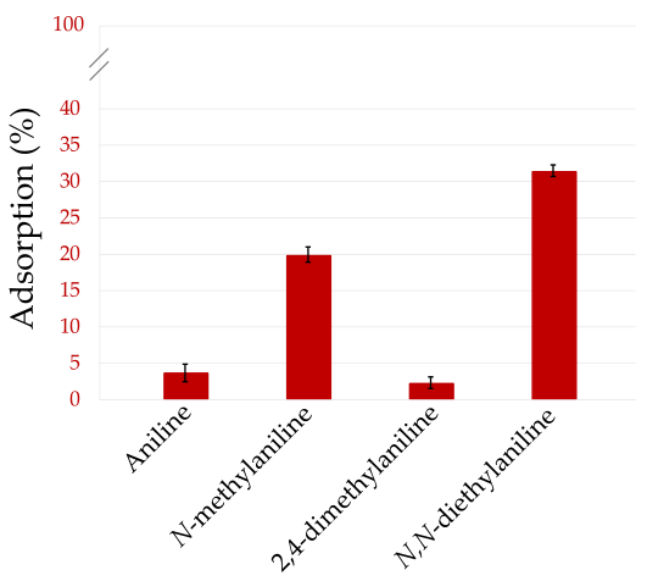

Aromatic amines

Figure 6. Graphical depiction of the adsorption performances of the composite with various aliphatic and aromatic amines. 
At this point, it is necessary to provide a more rigorous explanation to justify the different results obtained with aliphatic and aromatic amines by evaluating their chemical nature. The fundamental core of our procedure is based on the cationic exchange between the $\mathrm{SO}_{3} \mathrm{H}$ groups and the salified amines; therefore, delocalization and inductive effects become relevant in modifying the cation local charge density and the subsequent interaction strength.

In particular, some electronic effects can be invoked. When amines are in their hydrochloride form, an ionic couple between the ammonium ion and its counter anion $\left(\mathrm{Cl}^{-}\right)$is established. In this sense, the strength of the electrostatic interaction depends on the delocalization of the positive charge possessed by ammonium ion: the greater the substitution degree of the amine, the more the positive charge will be stabilized. A better stabilization leads the cations to interact less with their counter ions, which form hydrogen bonds with the hydroxyl groups of the cellulose backbone [70]. Therefore, the cations become free to take part in the exchange interactions with the $-\mathrm{SO}_{3} \mathrm{H}$ groups on the composite's surface. As result, the efficiency of the overall extraction of the amine from the aqueous system is improved. For these reasons, aliphatic tertiary and secondary amines as $\mathrm{N}, \mathrm{N}$-diisopropylethylamine and piperidine gave the best results.

Nonetheless, the hard-soft acid-base theory (HSAB) helps us explain the differences for the recovery percentages obtained for the aliphatic and aromatic species. In particular, the sulfate group exhibits a borderline behavior [71,72], while aliphatic ammonium ions are harder than the aromatic ones. Subsequently, the latter have a minor interaction with sulfate groups, providing a lower adsorption than aliphatic cations. In fact, the presence of one or two aliphatic substituents with the aromatic one on amine group, such as for $\mathrm{N}$-methylaniline and $\mathrm{N}, \mathrm{N}$-dimethylaniline, partially reduces the effect due to the aromatic ring, while not increasing the adsorption up to levels of the aliphatic amines.

Furthermore, steric effects too can not be excluded as reported by Fraser Steel et al. [73]. For the case of 4-methoxybenzylamine, a - $\mathrm{CH}_{2}$ group separates the ammonium system from the aromatic moiety: this feature precludes the resonance stabilization, making the cation harder than the other aromatic amines. Nonetheless, its recovery percentage is worse than the data reported for $\mathrm{N}$-methylaniline and $\mathrm{N}, \mathrm{N}$-diethylaniline and very different from the results obtained for the other aliphatic analytes. Steric hindrance can also contribute to explain why the percentages obtained for 2-ethylhexylamine are slightly better than the adsorption of 1,5-dimethylhexylamine, even if electronic effects should privilege the latter.

Moreover, the adsorption capacity of magnetic nanocellulose not sulfonated was evaluated on the amine with the best performance, $N, N$-diisopropylethylamine, observing a very low result $(\cong 2 \%)$. Therefore, it can be concluded that the adsorption activity is due to the sulfonic group presence on the surface on the cellulose nanomaterial.

Finally, the calculated loading factors $(\mathrm{Q})$ are listed in the following table (Table 2).

Table 2. Loading factors of the magnetic composite.

\begin{tabular}{cccc}
\hline Analyte & $\mathbf{Q}(\mathbf{m g} / \mathbf{g})$ & Analyte & $\mathbf{Q}$ (mg/g) \\
\hline Piperidine & 57.8 & 4-methoxybenzylamine & 4.8 \\
\hline N,N-diisopropylethylamine & 76.3 & Aniline & 2.4 \\
\hline 1,5-dimethylhexylamine & 56.0 & $N$-methylaniline & 11.9 \\
\hline 2-ethylhexylamine & 56.4 & 2,4-dimethylaniline & 1.4 \\
\hline Octylamine & 42.7 & N,N-diethylaniline & 19.9 \\
\hline
\end{tabular}

Finally, reusability experiments of the composite material were conducted on $\mathrm{N}, \mathrm{N}$-diisopropylethylamine. The obtained result demonstrated that after the first use (fresh $=94 \%$ ) and the first recycle at $92 \%$, the composite material lost its adsorptive properties, dramatically decreasing the absorption activity to $62 \%$. 


\section{Conclusions}

In summary, the preparation of a novel composite media and its application in environmental remediation were investigated. Magnetite-decorated sulfate cellulose nanoparticles (MDSCNs) were successfully synthetized and characterized. Then, they were used as an efficient system for water remediation from amine pollutants. The obtained results showed that even with a small amount of adsorbent $(100 \mathrm{mg})$, it was possible to reach adsorption percentages up to $90 \%$ for some aliphatic amines. These important achievements add another contribution to the environmental remediation of pollutants from anthropic impact, which is a matter that is a hot topic in environmental sciences. In this context, our material also proved to be easily recoverable thanks to its notable magnetic properties and, as future perspectives, further applications should be exploited to further explore the advantages that the derivative cellulose-based magnetic composite possessed. Among these, the use of smart liquid media with advanced properties [74,75], such as enhanced or anti-Arrhenian conductivity or even response to a magnetic field, will certainly be tailored in light of synergetically coupling these properties with those of our nanoparticles for specific applications of ever-increasing added values.

Supplementary Materials: The following are available online at http:/www.mdpi.com/2076-3417/10/22/8155/s1, Figure S1: IR spectra of $\mathrm{Fe}_{3} \mathrm{O}_{4}$ nanoparticles; Figure S2: IR spectra of microcrystalline cellulose (MCC); Figure S3: IR spectra of sulfonated cellulose (SC); Figure S4: IR spectra of $\mathrm{SC} @ \mathrm{Fe}_{3} \mathrm{O}_{4}$; Figure S5: IR spectra of sulfonated cellulose @ $\mathrm{Fe}_{3} \mathrm{O}_{4}$ composite after absorption; Table S1: Assignment resume of the vibrational peaks; Figure S6: Piperidine calibration curve; Figure S7: N,N-Diisopropylethylamine calibration curve; Figure S8: 1,5-Dimethylhexylamine calibration curve; Figure S9: 2-Ethylhexylamine calibration curve; Figure S10: Octylamine calibration curve; Figure S11: 4-Methoxybenzylamine calibration curve; Figure S12: Aniline calibration curve; Figure S13: N-Methylaniline calibration curve; Figure S14: 2,4-Dimethylaniline calibration curve; Figure S15: N,N-Diethylaniline calibration curve; Table S2: Peak data; Table S3: GC analytical method; Figure S16: Chromatogram of piperidine; Figure S17: Chromatogram of $N, N$-diisopropylehtylamine; Figure S18: Chromatogram of 1,5-dimethylhexylamine; Figure S19: Chromatogram of 2-ethylhexylamine; Figure S20: Chromatogram of octylamine; Figure S21: Chromatogram of 4-methoxybenzylamine; Figure S22: Chromatogram of aniline; Figure S23: Chromatogram of $N$-methylaniline; Figure S24: Chromatogram of 2,4-dimethylaniline; Figure S25: Chromatogram of $N, N$-diethylaniline.

Author Contributions: Conceptualization, A.D.N., L.M., M.A.T. and V.A.; methodology, M.A.T., V.A., F.O.; formal analysis, G.D.F., M.A.T., V.A.; investigation, A.D.N., L.M., P.C.; data curation, M.A.T., V.A., F.O.; writing — original draft preparation, L.M., M.A.T. and V.A.; writing—review and editing, A.D.N. and L.M.; supervision, A.D.N. and L.M.; funding acquisition, A.D.N., L.M., P.C. All authors have read and agreed to the published version of the manuscript.

Funding: This research received no external funding.

Acknowledgments: This research was supported by the project FOREST-COMP_CUP H56C18000080005-PON "Ricerca e Innovazione 2014-2020". University of Calabria and Calabria Region (PAC CALABRIA 2014-2020-Asse Prioritario 12, Azione B 10.5.12 CUP: H28D19000040006) are acknowledged for financial support.

Conflicts of Interest: The authors declare no conflict of interest.

\section{References}

1. Lim, E.K.; Kim, T.; Paik, S.; Haam, S.; Huh, Y.M.; Lee, K. Nanomaterials for Theranostics: Recent Advances and Future Challenges. Chem. Rev. 2015, 115, 327-394. [CrossRef] [PubMed]

2. Smith, B.R.; Gambhir, S.S. Nanomaterials for in Vivo Imaging. Chem. Rev. 2017, 117, 901-986. [CrossRef] [PubMed]

3. Lombardo, D.; Calandra, P.; Pasqua, L.; Magazù, S. Self-Assembly of Organic Nanomaterials and Biomaterials: The Bottom-Up Approach for Functional Nanostructures Formation and Advanced Applications. Materials 2020, 13, 1048. [CrossRef] [PubMed]

4. Lombardo, D.; Calandra, P.; Barreca, D.; Magazù, S.; Kiselev, M.A. Soft Interaction in Liposome Nanocarriers for Therapeutic Drug Delivery. Nanomaterials 2016, 6, 125. [CrossRef]

5. Cai, W.; Wang, J.; Chu, C.; Chen, W.; Wu, C.; Liu, G. Metal-Organic Framework-Based Stimuli-Responsive Systems for Drug Delivery. Adv. Sci. 2019, 6, 1801526. [CrossRef]

6. Lee, S.H.; Song, J.G.; Han, H.K. Development of pH-responsive organic-inorganic hybrid nanocomposites as an effective oral delivery system of protein drugs. J. Control. Release 2019, 311-312, 74-84. [CrossRef] 
7. Patra, J.K.; Das, G.; Fraceto, L.F.; Campos, E.V.R.; Rodriguez-Torres, M.D.P.; Acosta-Torres, L.S.; Diaz-Torres, L.A.; Grillo, R.; Swamy, M.K.; Sharma, S.; et al. Nano based drug delivery systems: Recent developments and future prospects. J. Nanobiotechnol. 2018, 16, 1-33. [CrossRef]

8. Sabu, T.; Pasquini, D.; Leu, S.; Gopakumar, D.A. Nanoscale Materials in Water Purification, 1st ed.; Elsevier: Amsterdam, The Netherlands, 2018; ISBN 9780128139264.

9. Singh, T.; Shukla, S.; Kumar, P.; Wahla, V.; Bajpai, V.K. Application of Nanotechnology in Food Science: Perception and Overview. Front. Microbiol. 2017, 8, 1-7. [CrossRef]

10. Calandra, P.; Caschera, D.; Turco Liveri, V.; Lombardo, D. How self-assembly of amphiphilic molecules can generate complexity in the nanoscale. Colloids Surf. A Physicochem. Eng. Asp. 2015, 484, 164-183. [CrossRef]

11. Khan, I.; Saeed, K.; Khan, I. Nanoparticles: Properties, applications and toxicities. Arab. J. Chem. 2017, 12, 908-931. [CrossRef]

12. Cornell, R.M.; Schwertmann, U. The Iron Oxides, 2nd ed.; Wiley-VCH: Weinheim, Germany, 2003; ISBN 3527302743.

13. Dulińska-Litewka, J.; Łazarczyk, A.; Hałubiec, P.; Szafrański, O.; Karnas, K.; Karewicz, A. Superparamagnetic iron oxide nanoparticles-current and prospective medical applications. Materials 2019, 12, 617. [CrossRef] [PubMed]

14. Teja, A.S.; Koh, P.Y. Synthesis, properties, and applications of magnetic iron oxide nanoparticles. Prog. Cryst. Growth Charact. Mater. 2009, 55, 22-45. [CrossRef]

15. Abenojar, J.; López de Armentia, S.; Barbosa, A.Q.; Martínez, M.A.; Velasco, F.; da Silva, L.F.M.; del Real Romero, J.C. Coating cork particles with iron oxide: Effect on magnetic properties. Wood Sci. Technol. 2020, 54, 869-889. [CrossRef]

16. Dong, Y.; Yan, Y.; Zhang, Y.; Zhang, S.; Li, J. Combined treatment for conversion of fast-growing poplar wood to magnetic wood with high dimensional stability. Wood Sci. Technol. 2016, 50, 503-517. [CrossRef]

17. Demangeat, E.; Pédrot, M.; Dia, A.; Bouhnik-Le-Coz, M.; Grasset, F.; Hanna, K.; Kamagate, M.; Cabello-Hurtado, F. Colloidal and chemical stabilities of iron oxide nanoparticles in aqueous solutions: The interplay of structural, chemical and environmental drivers. Environ. Sci. Nano 2018, 5, 992-1001. [CrossRef]

18. Chekli, L.; Phuntsho, S.; Roy, M.; Lombi, E.; Donner, E.; Shon, H.K. Assessing the aggregation behaviour of iron oxide nanoparticles under relevant environmental conditions using a multi-method approach. Water Res. 2013, 47, 4585-4599. [CrossRef]

19. Blackburn, R.S. Natural Polysaccharides and Their Interactions with Dye Molecules: Applications in Effluent Treatment. Environ. Sci. Technol. 2004, 38, 4905-4909. [CrossRef]

20. Alsbaiee, A.; Smith, B.J.; Xiao, L.; Ling, Y.; Helbling, D.E.; Dichtel, W.R. Rapid removal of organic micropollutants from water by a porous $\beta$-cyclodextrin polymer. Nature 2016, 529, 190-194. [CrossRef]

21. Crini, G. Studies on adsorption of dyes on beta-cyclodextrin polymer. Bioresour. Technol. 2003, 90, $193-198$. [CrossRef]

22. Miretzky, P.; Cirelli, A.F. Cr(VI) and Cr(III) removal from aqueous solution by raw and modified lignocellulosic materials: A review. J. Hazard. Mater. 2010, 180, 1-19. [CrossRef]

23. Abdolali, A.; Guo, W.S.; Ngo, H.H.; Chen, S.S.; Nguyen, N.C.; Tung, K.L. Typical lignocellulosic wastes and by-products for biosorption process in water and wastewater treatment: A critical review. Bioresour. Technol. 2014, 160, 57-66. [CrossRef] [PubMed]

24. Vitas, S.; Keplinger, T.; Reichholf, N.; Figi, R.; Cabane, E. Functional lignocellulosic material for the remediation of copper(II) ions from water: Towards the design of a wood filter. J. Hazard. Mater. 2018, 355, 119-127. [CrossRef] [PubMed]

25. Isikgor, F.H.; Becer, C.R. Lignocellulosic biomass: A sustainable platform for the production of bio-based chemicals and polymers. Polym. Chem. 2015, 6, 4497-4559. [CrossRef]

26. Zhao, X.; Zhang, L.; Liu, D. Biomass recalcitrance. Part I: The chemical compositions and physical structures affecting the enzymatic hydrolysis of lignocellulose. Biofuels Bioprod. Biorefining 2012, 6, 465-482. [CrossRef]

27. Yang, H. Characteristics of hemicellulose, cellulose and lignin pyrolysis. Fuel 2007, 86, 1781-1788. [CrossRef]

28. Aloulou, F.; Boufi, S.; Labidi, J. Modified cellulose fibres for adsorption of organic compound in aqueous solution. Sep. Purif. Technol. 2006, 52, 332-342. [CrossRef]

29. Fakhre, N.A.; Ibrahim, B.M. The use of new chemically modified cellulose for heavy metal ion adsorption. J. Hazard. Mater. 2018, 343, 324-331. [CrossRef] 
30. Jamshaid, A.; Hamid, A.; Muhammad, N.; Naseer, A.; Ghauri, M.; Iqbal, J.; Rafiq, S.; Shah, N.S. Cellulose-based Materials for the Removal of Heavy Metals from Wastewater-An Overview. ChemBioEng Rev. 2017, 4, 240-256. [CrossRef]

31. Dalpozzo, R.; De Nino, A.; Maiuolo, L.; Nardi, M.; Procopio, A.; Russo, B.; Tagarellia, A. Erbium triflate: A valuable and non-toxic catalyst for the synthesis of acylals and enol esters. Arkivoc 2006, 6, 181-189. [CrossRef]

32. Dalpozzo, R.; De Nino, A.; Bartoli, G.; Bosco, M.; Sambri, L.; Marcantoni, E. Synthesis of $\beta, \gamma$-Unsaturated Ketones via Cerium-Mediated Addition of Organolithiums to Silylated Enaminones. J. Org. Chem. 1998, 63, 3745-3747. [CrossRef]

33. Maiuolo, L.; Feriotto, G.; Algieri, V.; Nardi, M.; Russo, B.; Di Gioia, M.L.; Furia, E.; Tallarida, M.A.; Mischiati, C.; De Nino, A. Antiproliferative activity of novel isatinyl/indanyl nitrones (INs) as potential spin trapping agents of free radical intermediates. MedChemComm 2018, 9, 299-304. [CrossRef] [PubMed]

34. Bortolini, O.; De Nino, A.; Garofalo, A.; Maiuolo, L.; Procopio, A.; Russo, B. Erbium triflate in ionic liquids: A recyclable system of improving selectivity in Diels-Alder reactions. Appl. Catal. A Gen. 2010, 372, $124-129$. [CrossRef]

35. Romeo, I.; Olivito, F.; Tursi, A.; Algieri, V.; Beneduci, A.; Chidichimo, G.; Maiuolo, L.; Sicilia, E.; De Nino, A. Totally green cellulose conversion into bio-oil and cellulose citrate using molten citric acid in an open system: Synthesis, characterization and computational investigation of reaction mechanisms. RSC Adv. 2020, 10, 34738-34751. [CrossRef]

36. Calandra, P.; de Caro, T.; Caschera, D.; Lombardo, D.; Todaro, L.; Turco Liveri, V. Spectroscopic and structural characterization of pure and FeCl3-containing tri-n-butyl phosphate. Colloid Polym. Sci. 2014, 293, 597-603. [CrossRef]

37. Calandra, P.; Ruggirello, A.; Mele, A.; Liveri, V.T. Self-assembly in surfactant-based liquid mixtures: Bis(2-ethylhexyl)phosphoric acid/bis(2-ethylhexyl)amine systems. J. Colloid Interface Sci. 2010, 348, 183-188. [CrossRef] [PubMed]

38. Calandra, P.; Mandanici, A.; Liveri, V.T. Self-assembly in surfactant-based mixtures driven by acid-base reactions: Bis(2-ethylhexyl) phosphoric acid-n-octylamine systems. RSC Adv. 2013, 3, 5148-5155. [CrossRef]

39. Calandra, P. On the physico-chemical basis of self-nanosegregation giving magnetically-induced birefringence in dibutyl phosphate/bis(2-ethylhexyl) amine systems. J. Mol. Liq. 2020, 310, 113186. [CrossRef]

40. Mehta, D.; Mazumdar, S.; Singh, S.K. Magnetic adsorbents for the treatment of water/wastewater-A review. J. Water Process Eng. 2015, 7, 244-265. [CrossRef]

41. Shi, W.; Zhou, Y.; Zhang, Y.; Li, L.; Yang, Q. Synthesization, characterization and adsorption properties of sulfonic cellulose. Water Sci. Technol. 2012, 66, 2638-2646. [CrossRef]

42. Xu, C.; Yu, T.; Peng, J.; Zhao, L.; Li, J.; Zhai, M. Efficient Adsorption Performance of Lithium Ion onto Cellulose Microspheres with Sulfonic Acid Groups. Quantum Beam Sci. 2020, 4, 6. [CrossRef]

43. Liu, M.; Huang, J.; Deng, Y. Adsorption behaviors of l-arginine from aqueous solutions on a spherical cellulose adsorbent containing the sulfonic group. Bioresour. Technol. 2007, 98, 1144-1148. [CrossRef] [PubMed]

44. Shet, R.T.; Wallajapet, P.R.R. Sulfonated Cellulose Having Absobent Properties. Patent WO 97/21733, 19 June 1997.

45. Poste, A.E.; Grung, M.; Wright, R.F. Amines and amine-related compounds in surface waters: A review of sources, concentrations and aquatic toxicity. Sci. Total Environ. 2014, 481, 274-279. [CrossRef]

46. Lichtfouse, E.; Schwarzbauer, J.; Robert, D. Pollutants in Buildings, Water and Living Organisms; Lichtfouse, E., Schwarzbauer, J., Robert, D., Eds.; Springer: Berlin/Heidelberg, Germany, 2015; ISBN 9783319192765.

47. Eide-Haugmo, I.; Brakstad, O.G.; Hoff, K.A.; Sørheim, K.R.; da Silva, E.F.; Svendsen, H.F. Environmental impact of amines. Energy Procedia 2009, 1, 1297-1304. [CrossRef]

48. Ma, F.; Wan, Y.; Yuan, G.; Meng, L.; Dong, Z.; Hu, J. Occurrence and Source of Nitrosamines and Secondary Amines in Groundwater and its Adjacent Jialu River Basin, China. Environ. Sci. Technol. 2012, 46, 3236-3243. [CrossRef] [PubMed]

49. Song, P.; Wu, L.; Guan, W. Dietary nitrates, nitrites, and nitrosamines intake and the risk of gastric cancer: A meta-analysis. Nutrients 2015, 7, 9872-9895. [CrossRef] [PubMed] 
50. Sahoo, A.; Patra, S. A magnetically separable and recyclable g-C3N4/Fe3O4/porous ruthenium nanocatalyst for the photocatalytic degradation of water-soluble aromatic amines and azo dyes. RSC Adv. 2020, 10, 6043-6051. [CrossRef]

51. Yu, J.G.; Zhao, X.H.; Yang, H.; Chen, X.H.; Yang, Q.; Yu, L.Y.; Jiang, J.H.; Chen, X.Q. Aqueous adsorption and removal of organic contaminants by carbon nanotubes. Sci. Total Environ. 2014, 482-483, 241-251. [CrossRef] [PubMed]

52. Chen, W.; Duan, L.; Wang, L.; Zhu, D. Adsorption of hydroxyl- and amino-substituted aromatics to carbon nanotubes. Environ. Sci. Technol. 2008, 42, 6862-6868. [CrossRef] [PubMed]

53. Akhlaghi Bagherjeri, M.; Nikoodel, M.; Hosseini, M.S.; Tanipour, M.H. Investigation on Adsorption Behavior of Some Pollutant Aromatic Amines onto Bentonite by Spectrofluorometric Method. Polycycl. Aromat. Compd. 2020, 40, 1112-1126. [CrossRef]

54. Zavareh, S.; Avanes, A.; Beiramyan, P. Effective and selective removal of aromatic amines from water by $\mathrm{Cu}^{2+}$-treated chitosan/alumina nanocomposite. Adsorpt. Sci. Technol. 2017, 35, 218-240. [CrossRef]

55. Liu, B.; Zhang, Z.; Huang, K. Cellulose sulfuric acid as a bio-supported and recyclable solid acid catalyst for the synthesis of 5-hydroxymethylfurfural and 5-ethoxymethylfurfural from fructose. Cellulose 2013, 20, 2081-2089. [CrossRef]

56. Safari, J.; Banitaba, S.H.; Khalili, S.D. Cellulose sulfuric acid catalyzed multicomponent reaction for efficient synthesis of 1,4-dihydropyridines via unsymmetrical Hantzsch reaction in aqueous media. J. Mol. Catal. A Chem. 2011, 335, 46-50. [CrossRef]

57. Shaabani, A.; Maleki, A. Cellulose sulfuric acid as a bio-supported and recyclable solid acid catalyst for the one-pot three-component synthesis of $\alpha$-amino nitriles. Appl. Catal. A Gen. 2007, 331, 149-151. [CrossRef]

58. Rahmatpour, A. Cellulose sulfuric acid as a biodegradable and recoverable solid acid catalyst for one pot synthesis of substituted pyrroles under solvent-free conditions at room temperature. React. Funct. Polym. 2011, 71, 80-83. [CrossRef]

59. Lassalle, V.L.; Zysler, R.D.; Ferreira, M.L. Novel and facile synthesis of magnetic composites by a modified co-precipitation method. Mater. Chem. Phys. 2011, 130, 624-634. [CrossRef]

60. Zhang, K.; Peschel, D.; Bäucker, E.; Groth, T.; Fischer, S. Synthesis and characterisation of cellulose sulfates regarding the degrees of substitution, degrees of polymerisation and morphology. Carbohydr. Polym. 2011, 83, 1659-1664. [CrossRef]

61. Calandra, P.; Caponetti, E.; Chillura Martino, D.; D'Angelo, P.; Minore, A.; Turco Liveri, V. FT-IR and dielectric study of water/AOT liquid crystals. J. Mol. Struct. 2000, 522, 165-178. [CrossRef]

62. Lee, C.M.; Kubicki, J.D.; Fan, B.; Zhong, L.; Jarvis, M.C.; Kim, S.H. Hydrogen-Bonding Network and OH Stretch Vibration of Cellulose: Comparison of Computational Modeling with Polarized IR and SFG Spectra. J. Phys. Chem. B 2015, 119, 15138-15149. [CrossRef]

63. Lee, C.M.; Mohamed, N.M.A.; Watts, H.D.; Kubicki, J.D.; Kim, S.H. Sum-frequency-generation vibration spectroscopy and density functional theory calculations with dispersion corrections (DFT-D2) for cellulose I $\alpha$ and I $\beta$. J. Phys. Chem. B 2013, 117, 6681-6692. [CrossRef]

64. Wiley, J.H.; Atalla, R.H. Band assignments in the raman spectra of celluloses. Carbohydr. Res. 1987, 160, 113-129. [CrossRef]

65. Blackwell, J. Infrared and Raman spectroscopy of cellulose. Cellul. Chem. Technol. 1977, 14, $206-218$.

66. Tsuboi, M. Infrared spectrum and crystal structure of cellulose. J. Polym. Sci. 1957, 25, 159-171. [CrossRef]

67. Ciolacu, D.; Ciolacu, F.; Popa, V.I. Amorphous Cellulose-Structure and Characterization. Cell. Chem. Technol. 2011, 45, 13-21.

68. Titov, E.V.; Rybachenko, V.I.; Makarova, R.A. The IR spectroscopic characteristics of sulfo group vibrations and the structure of some N-sulfonylammonium salts. J. Appl. Spectrosc. 1979, 31, 1390-1394. [CrossRef]

69. Li, X.; He, Y.; Sui, H.; He, L. One-step fabrication of dual responsive lignin coated Fe3O4 nanoparticles for efficient removal of cationic and anionic dyes. Nanomaterials 2018, 8, 162. [CrossRef] [PubMed]

70. Zhao, Y.; Liu, X.; Wang, J.; Zhang, S. Effects of cationic structure on cellulose dissolution in ionic liquids: A molecular dynamics study. ChemPhysChem 2012, 13, 3126-3133. [CrossRef]

71. Cechinel, M.A.P.; Mayer, D.A.; Mazur, L.P.; Silva, L.G.M.; Girardi, A.; Vilar, V.J.P.; de Souza, A.A.U.; Selene, S.M.A. Application of ecofriendly cation exchangers (Gracilaria caudata and Gracilaria cervicornis) for metal ions separation and recovery from a synthetic petrochemical wastewater: Batch and fixed bed studies. J. Clean. Prod. 2018, 172, 1928-1945. [CrossRef] 
72. Yipmantin, A.; Maldonado, H.J.; Ly, M.; Taulemesse, J.M.; Guibal, E. Pb(II) and Cd(II) biosorption on Chondracanthus chamissoi (a red alga). J. Hazard. Mater. 2011, 185, 922-929. [CrossRef]

73. Steele, D.F.; Edge, S.; Tobyn, M.J.; Moreton, R.C.; Staniforth, J.N. Adsorption of an amine drug onto microcrystalline cellulose and silicified microcrystalline cellulose samples. Drug Dev. Ind. Pharm. 2003, 29, 475-487. [CrossRef]

74. Calandra, P.; Turco Liveri, V.; Riello, P.; Freris, I.; Mandanici, A. Self-assembly in surfactant-based liquid mixtures: Octanoic acid/Bis(2-ethylhexyl)amine systems. J. Colloid Interface Sci. 2012, 367, 280-285. [CrossRef]

75. Calandra, P.; Turco Liveri, V.; Ruggirello, A.M.; Licciardi, M.; Lombardo, D.; Mandanici, A. Anti-Arrhenian behaviour of conductivity in octanoic acid-bis(2-ethylhexyl)amine systems: A physico-chemical study. J. Mater. Chem. C 2015, 3, 3198-3210. [CrossRef]

Publisher's Note: MDPI stays neutral with regard to jurisdictional claims in published maps and institutional affiliations.

(C) 2020 by the authors. Licensee MDPI, Basel, Switzerland. This article is an open access article distributed under the terms and conditions of the Creative Commons Attribution (CC BY) license (http://creativecommons.org/licenses/by/4.0/). 